\title{
USING GIBBS' REFLECTIVE CYCLE IN MAKING REFLECTIONS OF LITERARY ANALYSIS
}

\author{
Ikin Syamsudin Adeani \\ Department of Indonesian Language Education Program, Faculty of Teachers Training and Education, \\ Universitas Galuh, Indonesia \\ E-mail: ikinsyamsudinadeani@gmail.com \\ R. Bunga Febriani \\ Department of English Education Program, Faculty of Teachers Training and Education, \\ Universitas Galuh, Indonesia \\ E-mail: bunga.febriani@gmail.com \\ Syafryadin \\ Department of English Education Postgraduate Program, Faculty of Teachers Training and Education, \\ Universitas Bengkulu, Indonesia \\ E-mail: syafryadin@unib.ac.id
}

\begin{abstract}
APA Citation: Adeani, I. S., Febriani, R. B., \& Syafryadin. (2020). Using GIBBS' reflective cycle in making reflections of literary analysis. Indonesian EFL Journal, 6(2), 139-148. doi: 10.25134/ieflj.v6i2.3382.
\end{abstract}

Received: 12-12-2019

Accepted: 02-04-2020

Published: 01-07-2020

\begin{abstract}
In English as Foreign Language (EFL) classroom context, it is compulsory for the students to make reflections of literary works. The current study is aimed at examining how the students implement Gibbs' reflective cycle in making reflections of literary analysis. The qualitative study employed a document analysis upon the students' reflection artefacts. The students' reflections are their responses to a short story written by Amy Tan. The findings of the study revealed that Gibbs' reflective cycle is a good framework to be used by the students in writing reflections upon literary works they are working on. The well-structured framework of writing reflection helped the students explore the literary work deeply, since the reflective cycle accommodates important aspects that can be explored from the literary work by the students. It can be concluded from this study that among the models of reflective writing developed by Kolb, Johnson, and Gibbs, the latest model is considered the most suitable to be used in literary classroom since its wellstructured model enables the students to write better reflections of literary works.
\end{abstract}

Keywords: reflective writing; Gibbs' reflective cycle framework; literary works; literary analysis.

\section{INTRODUCTION}

Literary works are designed to conceal the authors' intention so that readers need to interpret these intentions by making some kinds of analysis and evaluation of the works. Reading literary works means attempting to reveal the authors' true intentions to us, as readers. To understand and to interpret a literary work, it is necessary that a reader possesses the ability to think critically. This ability helps the reader in analyzing and giving evaluation towards the literary works.

Reading literary works and writing responses towards them are two interrelated activities. When one reads a novel, for instance, he/she might feel something about it, question things that happen in the story, analyze the story to answer his/her own questions, relate the characters of the story with his/her own life, and so on. On the other hand, as Rosenblatt (1988) called it, a reader is making a transaction with the literary text. As for writing, in the context of responding to literary works, writing plays an important role since it becomes something that a reader puts his/her thoughts in. Roberts and Jacobs (2004) stated that the goal of writing is to show a process of thought. He emphasized that as a reader writer needs to realize that the aim of writing is to explain something that she/he is analyzing. $\mathrm{He}$ suggested that a reader does not simply restate the events in the works. The interrelationship between reading and writing the literary works is in accordance with Rosenblatt' transactional theory which said that reading and writing is involved with text. As also explained by Febriani (2019), that echoed Rosenblatt that

Writing and reading is distinguished that a writer starts with a blank page and must produce a text, and a reader starts with already-written or printed text and must produce meaning. Similar to the reading and writing analogy, the term 
transaction, as she explained, is used to explain the relationships in which each element conditions and is conditioned by the other in a mutually constituted situations. (Febriani, 2019; p.37)"

One of the ways the readers of literary works manifest their interpretation and opinion towards literary works is by writing a reflective journal, or reflection. In expressing out what one had in mind while and after reading a story or a literary work, some researchers suggest that he/she writes his/her reflection towards the literary work. Reflection offers a writer reader the opportunity to consider how his/her personal experiences and observations shape his/her thinking and acceptance of new ideas. It encourages one to explore his/her own ideas about a text, to express his/her opinion rather than summarize the opinions of others. By putting his/her personal experiences and observation into written work, a reader can revisit and reconsider their thoughts in the future.

In the context of English as Foreign Language classroom, in literary subject classes, making reflections of literary works is compulsory for the students. This is one of the ways to acknowledge what the students have learned and interpreted after they have been assigned to read literary works. Through the students' reflections, the teacher can assess and examine how the students respond to literary works; the teacher can notice whether the students have got the author's implied intention; the teacher can anticipate when the students appear to misinterpret the stories of the literary works, and so on. Bubnys (2010) believed that making reflection is a basic for successful learners' activity analysis and the learning from one's own experience. He also stated that in the context of Higher education, it is a continuous educational process that encompasses the content, process, and premises.

This study is important to be carried out considering literary works demands language learners to be able to comprehend literature not merely from its intrinsic features. Moreover, they need to be able to revisit the works and relate them to their own experience. In other words, the language learners should understand things beyond what is stated in the literary works.

Previously, there have been research on the manifestation of reflective writing on literary analysis. One of the previous related research was conducted by Febriani (2019). She conducted a research that examine how reflective writing is manifested in the students' reader-response literary analysis. The study revealed that readerresponse prompts were helpful for the students that it gave the students ideas to write down their thoughts after reading literary works.

Another study was conducted by Middleton (2017). He sought to explore why critical reflection is difficult for some students. She also shared her personal experience of struggling with reflective models to critically reflect in a meaningful way. The findings revealed that critical reflection was a challenging task, since its process included a personal reflection that brought enlightenment, empowerment, and transformation that was not easy for anyone.

Hussein (2018) conducted a research which was aimed at examining the effect of reflective journals on students' learning, how they improve the growth mindset of the students, and the students' perceptions of the journaling process. The results of the study showed that the writing of reflective journal had a significant impact on EFL learners' concept comprehension.

Furthermore, Sekarwinahyu, Rustaman, Widodo, Riandi (2019) carried out the research on problem based learning and reflection skills of biology, the researchers used Gibbs model as an adopted model to be implemented in the classroom. Choo, Abdullah, Nawi (2018) also did a research on patterns of reflective practice in written journal. The result showed that Gibbs as good model to be implemented in reflective practice in writing a journal. Another researcher was Holder, Sim, Foong, Pallath (2019) who conducted the research on developing a reflection guiding tool for underperforming medical students. They applied Gibbs model in their research and the result showed that this Gibbs reflecting could cause awareness of the students regarding their skills.

Depart from the need for the students to write reflections to literary works and previous research, in the present study the writer is keen on conducting a study to examine how the students make reflections of literary works by using Gibb's reflective cycle. This current research is different from the previous research, even though the previous research implemented Gibbs Model, but the current research implemented it in literary works and it would may cause different findings. Among some other frameworks for writing reflection, the writer finds Gibb's reflective cycle is suitable to be implemented in the EFL literary subject classes, since it facilitates the students 
with a kind of more structured forms than the other frameworks. In other words, Gibb's reflective cycle has more clearly defined sections than other frameworks. Regarding such reasons, the writer formulates a research question for the current research: "How the students implement Gibbs' Reflective Cycle Framework in writing reflections of literary works?"

Literary works means the products of literature. In other words, literary works are the authentic materials of literature. In the study, literary works refers to the products of written literature. Literary works plays an important role in the teaching of literature to students, especially the students of English as Foreign Language. Widyahening and Wardhana (2016) described the functions of literary works according to Moody in 1984. They explained that there are four functions of literary works; firstly is to train four language skills; secondly, to add knowledge about human life experience such as customs, religion, culture, and so on; thirdly, to develop creation and feeling; lastly, to support character building.

To begin with, there are three genres of literature, namely Prose, Poetry, and Drama. The first literary genre to be discussed in the present study is prose. Prose is a genre of literature that takes the form of narrative text. The literary works that belong to the first genre are Short stories and novels. Since the genre takes the form of narrative text, it belongs to fiction. Thus, it has the elements of fiction. The elements of fiction cover the plot, characters, setting, point of view, theme, writing style, and symbolism. Plot in literary works means the events that make up a story. the events relate to each other in a sequence. There are two kinds of plot, chronological plot and flashback plot. The chronological plot moves according to the time sequence, meanwhile the latter means the kinds of plot that moves backwards and onwards in the time sequence. The characters in short stories and novels means the ones (any person, animal, or figures) represented in a literary work. The dominant character(s) in a story is called a protagonist, while the characters that are opposites to the protagonists are called antagonist characters. Setting in stories means the time and place where the story happens. It also includes the historical background, in which the author describes the situation and condition at the time and place when the story is told. In Prose (both in short stories and novels) the story is conveyed from the author to the reader through the story teller called narrator. Point of view in a short story is conveyed through the narrator's five senses. There are three kinds of point of view in prose: The first person's point of view, the third person's point of view, and the omniscient person's point of view. The story that uses the first person's point of view means that the narrator acts as one of the characters in the story. He tells the story based on what he sees, he hears, and he feels when he is interacting with other characters. Thus, the narrator in the first person's point of view story uses the pronoun "I" when delivering the story. In the story that uses the third person's point of view, the narrator delivers a story by choosing one character as the chosen character. In other words, he acts as an observer in the story. the story is delivered based on the chosen character's feelings. The narrator knows what happens in the story based on the interaction between the chosen characters and other characters. The Last but not least kind of point of view is omniscient person's point of view. It can be said that the narrator in the point of view is aknow-everything substance. He delivers the story without choosing one character as his eyes and ears, instead he knows everything on ever characters' mind. The narrator knows it all. This is why he is called omniscient. The next element of fiction is theme. It is the main idea of the whole story. It is usually stated in one complete sentence that summarize the entire story. The author's writing style is another element of fiction. It refers to how authors select the words they use in the stories. The last but not least element of fiction is symbolism. This is in accordance with the purpose of literature and literary works, that to conceal the real meanings to the readers. Literary works convey its messages implicitly so that readers need to be literature literate to be able to reveal the authors' messages through this kind of symbolism.

Glencoe (2010) sums up the differences between short stories and novels, as one of the literary genre, as follow. Firstly, that short stories encourage the readers to focus on one setting and a small numbers of actors. This means that the novels has the opposite characteristics, that it possesses more than one conflicts and a big number of characters. Secondly, that the plot development in short stories tends to be very compact, especially the exposition stage, the falling action stage, and the resolution stage. Next, when reading a short story, the readers need to determine the theme, by paying attention to what happens to the main character. Besides, the short story contains the point of view, in which 
the reader can notice whether the narrator is inside the story (first person's point of view) or outside the story (third person's point of view)

The second genre of literature is Drama. The literary works of drama is play. Plays are composed or written by so called playwrights (the writers of drama). Actually drama can be seen from two perspectives, one as a literary genre and the other as performance. In this study, the writer focus on the discussion of drama be seen from literature perspective. Drama or play is the kind of literary work that resembles prose, in the sense that it takes the form of literary text. One thing that distinguishes drama from prose is that drama uses dialogues rather than using a story teller or narrator. In other words, the story in drama is conveyed directly to the readers by using dialogues.

The third genre of literature is Poetry. The works of poetry is called poems. Poems are written by poets (the writers of poems). It is quite easy to differ poems with other literary genres, since it does not take the form of narrative text, and it also consists of patterns and forms which is obviously visible. Since Poems have certain patterns of writing, they can be analyzed in two ways, firstly by content, and secondly by the poetic devices. Poetic devices covers the patterns in the poems, such as stanza, verses, lines, rhymes, rhythm, figurative languages, and so on. Meanwhile content describes what the poet tells on his poem (subject), what he feels towards the subject of his poem (Feelings), what readers feel towards the poem (tone), and the what the poet aims by writing his poem (intention).

Literary works are different with those of other kinds of writings, such as news and factual texts like manual books, etc. Reading literary works needs the ability to think critically in order to understand what the authors intend to convey through their works. In other words, the readers need to be able to find the implied meanings beyond the stated ones. Analyzing literary works fulfills one of the purposes of teaching literature to the English as Foreign Language (EFL) Students, which is that teaching literature to the students encourages their critical thinking about plots, themes, characters, and so on.

Van (2009) reviewed and elaborated six approaches to literary analysis. The approaches are new criticism approach, structuralism approach, stylistic approach, reader-response approach, language-based approach, and critical literacy approach. other approaches in broader context of readers include historical approach, philosophical approach, formalism approach, psychological approach, feminist approach, marxist approach, and cultural approach.

Recently, Reflective writing, or also known as reflective journal, or reflection, has been widely used in the context of education and language learning. For the current research, the writer believes that Reader-response approach is the most suitable approach to work with literary works by using Gibbs' reflective cycle, since the approach to literary analysis encourages students to draw on their personal experiences, opinions, and feelings in their interpretation of literature, as described by Van (2009).

Generally, reflective writing is defined as a kind of academic writing that accommodates a reader writer to express his thoughts upon the literary works that he is reading. A reflective writing is a kind of personal academic writing; it is different with other kinds of academic writing. In this kind of writing, a reader writer does more than merely describing what has happened and how he is feeling when reading a literary work. The emphasis lies on the reader writer's analysis and exploration of the literary work. Also, the writer of a reflective writing usually use the first person ("I") to describe his analysis and feelings.

Thus, in responding to literary works, a critical reflection must be considered. As Watton et.al. (2001) asserted that even simple and basic questions such as "what is thesis?" and "what is the evidence?" are important to demonstrate one's understanding. Such questions interrogate one's own assumption and knowledge in order that he can deepen his analysis of the literary works.

One's reflective thinking towards a literary work can be manifested in a reflection. To mention some of the importance of writing reflection of literary works, there are some advantages to consider concerning the reflective writing. One of the purposes that one reflects is in order to consider the process of his own learning, to critically review something, in this case literary works, to build theory from observations, to engage in personal or self-development, to make decisions or resolve uncertainty, and to empower oneself as an individual. Regarding to this, Ross (2011) supported this view, stating that students are able to connect discrete pieces of information into meaningful ideas through this process of critical analysis.

As aforementioned, reflective writing or also known as reflection encourages the readers to explore their own ideas about a text. This means that after reading a text they do not merely 
summarize the text, instead, they express their opinion towards the text. Hussein (2018) supported this view by stating that reflective journals is a tool for alerting and guiding students in developing their learning. By referring to some previous studies on this field, he emphasized the importance of reflective journals focusing on the process of learning.

Generally speaking, there are some purposes of making reflection towards literary works. To mention some of them, first of all, readers of literary works reflect in order to consider the process of their own learning. Secondly, by making reflection, they critically review the works. Also, readers can be engaged in personal development with the literary works they are working on.

In writing reflections, there are some models to follow. As described by Hegarty (2011), practitioners reflect in different ways depending on the access that they have and also their existing skills for reflection. The models, or frameworks, encourage a well-organized process that guide the reflective writing activity. Although there are some models for making reflection, there is not so-called right model, or reflection. A reader writer may choose one model that is more suitable and able to assist him/her to learn from the literary works.

As when one reflects, he/she evaluate and relate one event to his/her own experience. Some of the fundamental questions of reflective writing in any model include (1) What am I learning?, (2) How am I learning?, (3) How am I using what I am Learning?, (4) what are my strengths and weaknesses? (5) What are my learning priorities? (6) How can I improve my learning, and (7) How well I am working towards my goals? (University College Cork)

Some of the models are Driscoll's model, John's model for structured reflection (2006), and Gibbs' model (1988). The first model of reflection to be discussed in the present study is Driscoll' model. He developed Driscoll' reflective cycle which consisted of three phases, which he called "What", "So What" and "Now What". The three models for writing reflections are actually acceptable for any fields of knowledge, not only for the context of education. however, in the present study, the writer narrows down the discussion by relating the models of reflective writing for educational purpose.

Reflection model is used as it provides a structure that enables the learners to evaluate learning, allow theories and concepts, and implement them in the practice (Wain, 2017). In her study, Wain (2017) also considered some other models including Kolb's and Johnson's which she considered particularly relevant to midwifery and education.

The first model of reflection is developed by Driscoll. He developed the cycle into three phases which he called "What" as the first phase, "So What" as the next phase, and "Now What" as the last phase. In the first phase a reader writer describes the event, situation or incident that he/she is reflecting on. In the context of making reflection of literary works, a reader writer writes the story/the subjects of the literary works (short stories, novels, poems, and drama) that he/she is reading. In "So What" phase, a reader writer tells what happened in the story, and also describes if the story is good or not, and the reasons why it is good or not.

The next phase in Driscoll's model of reflective cycle is called "So What". In This phase, the reader writer writes his/her analysis of the literary work. The phase is also called the analysis phase, which consists of how he/she feels when reading the literary work, how he/she reacts and the reason why he/she reacts that way when reading literary works, personal values and the ethics that influence him/her after reading the literary work, and other persons' feelings and reactions when reading similar literary works.

The last but not least phase of Driscoll's reflective cycle in the context of reading and analyzing literary works is the phase called "Now What". The phase is also called Action Planning stage. In the phase of reflection, a reader writer elaborates what he/she has learned from reflecting upon the literary work, explain what he/she might do if the events in the story happens to his/her own experience, and what he/she will do to help him/herself prepare for similar situations.

The second model of reflection is one that was developed by John (1993). The model or framework consists of four stages of cycle, namely Description of Experience, Reflection, Alternative Actions, and Learning stages. In the context of making reflections to literary works, in the first stage, Description of Experience stage, the reader writers explain the literary work they are working on (short stories, novels, drama, or poems). He/she explains the essential factors that contribute to the events happened in literary work. Moreover, he/she provides the significant background factors to the events in the work. In the second stage, reflection stage, the reader writer thinks of what he/she is trying to achieve 
by reading the work. Also he/she may think of the reasons that influence his/her thinking. The reflection stage also includes the reader writer's feelings about the literary works, and the reasons why he/she feels that way, etc. After sharing his/her reflection towards the literary work, a reader writer moves on to the third stage, that is Alternative Actions. In this stage, he/she thinks of the choice that he/she made in the previous stages and the consequences that may occur if he/she made the other choices. The last but not least stage in John's reflective cycle is called Learning stage. This stage contains some moral lessons that a reader gets after reading literary works, and how he/she will react when he/she is faced to similar situations in the future.

The Last but not least reflective cycle is developed by Gibbs (1988). Gibbs called his framework for writing reflection Gibbs' model of reflection. This cycle consists of six stages, which will be elaborated in the next part of the study. the writer believes that

In the context of writing a reflection upon a literary work in a language class (in English as Foreign Language context), the reflection should be written in a formal form since it is supposed to be assessed. In this case, it is important that a reader writer uses a framework of reflective writing. Actually, there are several models of reflection that can be used. One of the models is called Gibb's model of reflection (1988).

Gibb's model of reflection consists of six stages, covering Description, Feelings, Evaluation, Analysis, Conclusion, and Action Plan. In Description stage, a reader writer explains what he is reflecting on, including background information. He then discusses his feelings and thoughts about the literary works in Feeling stage. in this stage, he can discuss his emotions honestly. As the next stage of the model, in Evaluation, a reader writer discusses his reaction and also other people's reactions towards the story. This part is a good place to include theories and others' opinion. it has to be noted that it is important to include references in this academic writing. In Analysis stage, the reader writer relates to others' experiences and theories. In Conclusion, he acknowledges everything that he has written in the previous sections. The last but not the least stage is Action Plan. in this last part, a reader writer sums up anything and what he has to do to improve for next time.

The literary works that was selected to be discussed in the present study is a short story entitled "Two Kinds" which was written by Amy
Tan. The short story was chosen by considering some aspects. Firstly, the story brings a theme that is familiar for every one, which is a story about family. "Two Kinds" tells about a Chinese mother and her daughter in San Francisco. The mother who was an immigrant in United States, gave birth to her daughter, the first generation who was born in the USA. That aspect encouraged the writer to choose the short story to be discussed the present study that the story may be experienced by everyone. Almost every mother has conflicts with their daughters. In the story, conflicts of a mother and her daughter aroused by the different views and different choices. Another aspect to be considered when choosing the story in the study was that there were many to think of by the readers. It was not merely a short story to be read as a pleasure, but it was also fruitful of concealed meanings and contemplation.

Another aspect came from the consideration that readers were able to relate and notice the life of Chinese immigrants San Francisco at that time. To be noted, a crowd of immigrants from China came to United States in the middle of 1840 s, when a series of natural catastrophes emerged in China resulting in famine, peasant uprising and rebellions. Thus, it was understandable that when there was the news of gold and opportunities in faraway land reached China, many Chinese took the opportunity to look for their fortune (Chinatown Resource Guide. 2019). By administering the students (as the participants in the present study) to read the short story, the writer expected that the readers could reveal the true intention of the author from the short story, considering that one of the purposes of literary works was that they provide access to cultural background, as suggested by Lazar (1993).

The next aspect that triggered the writer to choose the short story entitled "Two Kinds" by Amy Tan was that it contained symbolism. As previously explained, symbolism in reading literary works plays an important role since it conceals the author's true intention. By administering the students to read this story, the writer expected that the students could improve their critical thinking when reading literary works. Glencoe (2010) reminded that "in literature, a symbolism is an ordinary object that has a larger meaning" (p.95). This echoed the previously described that the author of literary works concealed their true intention behind this kind of symbolism. 


\section{METHOD}

At the English Department of Universitas Galuh Ciamis, Literary subjects are among those subjects taught to the students. There are actually three subjects belong to literary subjects, namely Introduction to Literature, Literary Criticism, and Literature for Language Education. The first literary subject aims at introducing the students to literary genres and at exposing them to reading literary works, such as poems, short stories, novels, and drama. The second literary subject introduces literary analysis to the students and acknowledges to them the approaches to literary criticism. The last literary subject is to give the students insights of using literature in the language classroom; the subjects teaches how to implement the kinds of teaching methods by using literature.

Discussing how the students make use of Gibb's reflective cycle in writing reflections of literary works, the writer employed a qualitative research design. Qualitative method emphasizes on describing a particular activity, situation, field, behavior of people in-depth and a detailed way, as described by Fraenkel and Wallen, 2012). The present study examines how the students implement Gibb's reflective cycle (1988) in writing reflections of literary analysis. The qualitative study employed a document analysis upon the students' reflection artefacts. The students' reflections are their responses to a literary work (a short story) entitled "Two Kinds" written by Amy Tan. Therefore, document analysis is used as the qualitative research design, by using the students' reflective essays as the instrument to seek for how the students implement Gibb's reflective cycle in writing reflections of literary works.

The study was conducted upon nine students enrolling Literary Criticism subject class. One short story entitled "Two Kinds" written by Amy Tan was administered to be read by the students. The short story was chosen considering it brings a theme which might occur to everybody since the story reveals the relationship between a mother and her daughter. The students' reflective journals or reflection were analyzed to examine how they implement Gibb's Reflective Cycle in writing reflections of literary works. The students' reflection which used Gibb's cycle were compared to those that did not use Gibb's cycle of reflection. Comparing the reflections which used and which did not use Gibb's reflective cycle was considered helpful in examining how the students implemented the Gibbs' Reflective cycle when making reflections of their literary analysis.

\section{RESULTS AND DISCUSSION}

A brief explanation of reflective writing and Gibb's reflective cycle had previously explained in the previous section. The methodology for conducting this study had also been stated. In this section of the study, the writer presents the findings and discussion to the current study.

As aforementioned, this study is aimed at examining how the students implement Gibb's reflective cycle in writing their reflections towards literary works. The students' artefacts of their reflections of literary works have been analyzed in order that the writer is able to find out how they implemented Gibb's cycle in writing literary. By comparing the students' reflection which used Gibb's reflective cycle with those that did not use the cycle, the writer examined the difference of the result that the students make between those that implemented Gibbs' reflective cycle and those who did not making literary analysis of a literary work.

In the attempt to answer the research question addressed in the present study, "How the students implement Gibbs' Reflective Cycle Framework in writing reflections of literary works?", the writer compared some extracts of students which did not use Gibb's reflective cycle with those which used Gibb's reflective cycle.

The following is an extract of a reflection of The first student. In the reflection, she did not implement Gibbs' Reflective cycle as explained by Wain $(2017$, p. 663).

A beautiful kid named Jing-Mei believed that she can be anything in America. Jing-Mei believed that she could become rich, famous and smarter than other, just like what her mother always said. Her mother always Wanted her daughter to be an American prodigy. Hence, her mother prepared and coached Jing-Mei into becoming a Chinese Shirley Temple. her mother fully believed that Jing-Mei can make her dreams come true. To be a perfect person.

Every night after dinner her mother always test Jing-Mei's knowledge and abilities. Become of that, Jing-Mei grows resentful as she saw the disappointment on her mother's face as she failed to measure up to her expectations. And the test got harder and header in every single day.

One evening while watching The Ed Sullivan Show on television, her mother saw a young Chinese girl playing the piano with great skill. 
Then her mother thought to make Jing-Mei able to playing Piano, she forced her daughter to take piano lesson with Mr. Chong, who agrees to give Jing-Mei piano lessons in exchange for weekly house cleanings.

From the extract of the student' reflection upon the story "Two Kinds" by Amy Tan, it appeared that the student did not explore the short story deeply. Instead, she merely retelling the story. The student only described a girl named Jing Mei who had faith that she could be anything she wanted in America. She described that the girl's faith was in contrary to the mother of the girl, who expected her daughter to be someone beyond she was capable of, such as to be a prodigy. This expectation led the mother to push her daughter to be as successful as she wanted without willing to notice that her daughter had limitations in doing what her mother expected of her.

The following is the reflection made by the second student. The students implement the reflective cycle in the reflection.

Reflective writing of two kinds by Amy Tan. As we know that briefly, this story was telling us about a daughter named Jing-Mei who was forced by her mother to be the her best. But then the story turns badly when Jing-Mei try to disobeyed her mother. It seems so complicated then. However her mother was angry and their relationship turn badly. What I was feeling about this story are, first I'm so sad knowing that Jing-Mei's mother had bad memories in China. But then when Jing-Mei's mother forced Jing-Mei to do what her want I feel a little bit disappointed with Jing-Mei's mother. However whole story in this text was completely made me feel so many emotions. Hence it made me ask why them didn't tell each other about their feeling (?). The bad things that I can got from this story was probably the bad communication between mother and her daughter. Parents and their children must be honest to each other, they must be think to decided something wisely before the bad and unpredictable things happen. In fact, we shall find this kind of story in real life. When parents forced us to do something that they think good regardless their daughter's skill and competent. In conclusion I should say that this story is worth to read. This story already taught me how to be Better daughter and better mother in the future. How we have to respect our mother more than anything. How we have to know our children feel when we decide something for them. If this story happened to me. I as a daughter would say about my feeling wisely to my mother. So there aren't misunderstanding between us.
In the extract of the second reflection of the same student, it was quite obvious that the student explored the story deeper than that in the first extract. In the second extract, it could be noticed that the student had included her thoughts in it.

The description stage was found in the sentence: "As we know that briefly, this story was telling us about a daughter named Jing-Mei who was forced by her mother to be the her best. But then the story turns badly when Jing-Mei try to disobeyed her mother.". The student's reflection began with a brief description to help build the context to the reflection as a whole.

The feeling was found in the sentence: "What I was feeling about this story are, first I'm so sad knowing that Jing-Mei's mother had bad memories in China. But then when Jing-Mei's mother forced Jing-Mei to do what her want I feel a little bit disappointed with Jing-Mei's mother." In this part, the student acknowledged her reaction towards what happened to the main characters in the story.

The evaluation was found in the sentence: "The bad things that I can got from this story was probably the bad communication between mother and her daughter. Parents and their children must be honest to each other,...". In this part, the student's effort of evaluating the story was quite visible clearly. It appeared that the student had quite properly used her critical thinking.

The analysis was found in the sentence: "Parents and their children must be be honest to each other, they must be think to decided something wisely before the bad and unpredictable things happen. In fact, we shall find this kind of story in real life. When parents forced us to do something that they think good regardless their daughter's skill and competent."

The student concluded what she had explained in the reflection in the conclusion section. The conclusion was found in the sentence: "I should say that this story are worth to read. This story already taught me how to be Better daughter and better mother in the future."

The last but not the least, the student wrote "If this story happened to me. I as a daughter would say about my feeling wisely to my mother. So there aren't misunderstanding between us." As her action plan stage in case she had to face the situation in her real life.

The following is the last student's extract of reflection (Wain, 2017; p. 662).

In this story it is told that there is a mother who has forced her desire too much on her child (Jing- 
Mei). Jing-Mei's mother greatly obsessed her child into a successful child. I have felt very sorry for Jing-Mei for accepting coercion from her mother to do what her mother wants. I also felt sorry for them because of the lack of communication between them. if there is good communication between them there will definitely be no such thing. even I felt that they had failed, Jing-Mei's mother failed to be a mother who understood her child and Jing-Mei failed to be a successful child like what her mother wanted.

At first I felt sorry for Jing-Mei, but after reading to the end I felt annoyed. why is communication between them so bad? Shouldn't the communication between mother and child be good so that something fun happens? Jing-Mei should say if he wants to be himself and not want what her mother wants. Likewise, with her mother, she should also her daughter what she wanted first. in the end, regret happened, but I still felt salute to Jing Mei who wanted to learn piano again when their mother was gone. regret made him rise, not slump.

I have felt a little scared and sorry to read this story. The life of a mother and child who are out of sync with each other. a mother who has forced her own will and a child who has continued to do what her mother wants without seriousness. I personally have felt what Jing-Mei's felt. Because my father was a sports teacher, my father had demanded that I take part in sports-related activities. To be honest, I was the type of person who didn't like sports. I tried to be what my father wanted. I started participating in badminton, table tennis, volleyball, Pencak Silat and futsal at school, doing routine and serious training in school, sports arena, even at home with my father. And then, when I was in high school I took part in a high school sports match in the field of mixed doubles badminton to the provincial level and until I was runner up. My parents have been proud of what I have achieved, and I am satisfied and I enjoy it. now I like sports. Then when compared to this story, actually it's just about what JingMei's wants, if Jing-Mei want it, then do it seriously. but if not, then leave and pursue what Jing-Mei's want. if it is like that, then all will feel simple and pleasant.

Actually this is just about communication. If communication between them is good maybe this will not happen. If I was in a Jing-Mei's position, I guess I would say in a good way to my mother that I didn't want to do what my mother wanted if it really came out of my passion. I will try to earnestly pursue what suits my passion and be successful in a way that I want and make my mother proud instead of following my mother's will but not with seriousness. Action Plan I will discuss this matter seriously with my mother. I will ask for my mother's opinion what should I do when my mother's wishes do not match my passion. if my mother still wants what she wants, then I will try to be the best according to what my mother wants. and if my mother allows me to pursue what I want according to my passion, then I will try my hardest, show if I am able to succeed with the way I want.

The last student's reflection showed that the student had also succeeded in implementing the reflective cycle developed by Gibbs (1988). there were description, feelings, evaluation, analysis, conclusion, and action Plan, administered in each paragraph of the reflection. Reading a literary work, as aforementioned previously, is not merely reading a text for pleasure. Literary works of literature contained concealed meanings in the stories or drama or poems. Literature is meant to convey things implicitly. Most of times, readers must think beyond the ordinary meanings to find out the authors of the literary works' true intention in making such works. Comprehending literary works need the ability to think critically so that the readers can find the meanings beyond those that are not stated in the texts. Besides finding the authors' true intention, readers of literary works should be able to interact with the works as well. This is in accordance with the readers' critical thinking ability when being exposed to literary works. For instance, when reading a short story, the readers might interact with the story by questioning things, by feeling what the characters of the story feel, so that they will be able to analyze and evaluate the story.

Having compared nine extracts out of nine students upon one short story above, the writer can draw a conclusion that the most of students (eight) students implemented Gibbs' reflective cycle when making reflections of a short story written by Amy Tan, while one other did not implement the reflective cycle, or at least, he tried to do so yet the writing showed that he was not properly implement the Gibbs' reflective cycle. Comparing the reflections that implemented Gibbs' reflective cycle with the one that did not, the writer noticed that the well-structured framework of writing reflection helped the students explore the literary work deeply, not merely from the surface, since the reflective cycle accommodates important aspects that can be explored from the literary work by the students. This is visible that the one which did not implement the reflective cycle appeared to merely 
retelling the story without expressing out his own enjoyment (feelings) and opinion and judgement towards what happened in the story (analysis, evaluation, conclusion). Thus, he was unable to make an action plan of what he might be doing when similar situation happens in his own life in the future.

\section{CONCLUSION}

The present study has explored how the students implemented Gibb's reflective cycle (1988) in making reflections which respond to literary analysis. The focus of the study lies on how the students of a literary subject acknowledge the results of their reading on literary works. The reflection writing is emphasized merely in the content of their interpretation of literary works; the linguistic aspect in the literary reflection is indeed unconcerned. Therefore, we recommend the further researchers to not only pay attention to the content, but also to the language structure in writing reflection to literary works. The writer expects that by doing so, research on reflective writing in literary analysis can be fruitful and various in meaning.

\section{REFERENCES}

Bubnys, R. \& Žydžiūnaitè, V., (2010). Reflective learning models in the context of higher education: Concept analysis. Problems of Education in $21^{\text {st }}$ Century. 20 (1), 58-66.

Choo, Y.B., Abdullah, T., Nawi, A.M. (2018). Learn to teach: Patterns of reflective practice in written journal. LSP International Journal, 5(2), 50.

Febriani, R. B. (2019). The students' reflective writing manifestation of reader-response literary analysis. Journal of English Education, Literature, and Culture. 4(1). 35-44

Gibbs, G. (1988). Learning by doing: A guide to teaching and learning methods. Oxford: Oxford Further Education Unit

Glencoe. (2010). Literature: Teacher edition. New York: McGraw-Hill Companies, Inc.

Hegarty, B. (2011). A framework to guide professional learning and reflective practice. University of Wollongong Thesis Collection. Wollongong: University of Wollongong.
Holder, N.A.K., Sim, Z.L., Foong, C.C., Pallath, V. (2019). Developing a reflection guiding tool for underperforming medical students: An action research project. Tuning Journal for Higher Education, 7(1), 115-163

Hussein, H. (2018). Examining the effects of reflective journals on students' growth mindset: A case study of tertiary level EFL students in the United Arab Emirates. IAFOR Journal of Education, 6(2), 33-50.

Johns, C. (1993). Achieving effective work as a professional activity in towards advanced nursing practice (Ch11) Eds: Schober, JE., and Hinchliff SM., Arnold.

Lazar, G. (1993). Literature and language teaching. Cambridge: Cambridge University Press.

Middleton, R. (2017). Critical reflection on practice development: The struggle of a practice developer. International Practice Development Journal, 7(1), 41-46.

Roberts, E.V. \& Jacobs. H.E., (2004). Literature: An introduction to reading and writing. New Jersey: Pearson Prentice Hall.

Rosenblatt, L. (1988). Writing and reading the transactional theory. Wahington DC: The National Institute of Education.

Ross, N. (2011). Reflective writing: An approach to developing critical thinking \& proficient writing. New York: United States Military Academy.

Sekarwinahyu, M., Rustaman, N., Widodo, A., Riandi, R. (2019). Problems based learning skills and reflection skills of biology education students through the problem based online tutorial. Journal of Physics: Conference Series 1280 (2019) 032004

Tan, A. (2006) The joy luck club. New York: Penguin Print

Van, T.T.M., (2009). The relevance of literary analysis to teaching literature in The EFL classroom. English Teaching Forum, 47(3), 2-9.

Wain, A. (2017), Learning through reflection, British Journal of Midwifery, 25(10). 662-666

Watton, P., Collings, J., Moon, J., (2001). Reflective writing: Guidance notes for students. England: Exeter University

Widyahening, E. T. \& Wardhana, N. E. (2016). Literary works and character education. International Journal of Language and Literature, 4(1) 176-180. 